\title{
GAMBARAN PENGETAHUAN KADER TENTANG GIZI KURANG PADA BALITA DI KELURAHAN REJOSO KLATEN
}

\author{
Description Of Cader Knowledge About Less Nutrition Balita In \\ Rejoso Klaten District \\ Ajeng Novita Sari $^{1}$, Danik Riawati ${ }^{2}$ \\ STIKES Mamba'ul 'Ulum Surakarta \\ ajeng.novitasari@stikesmus.ac.id, danikriawati@yahoo.co.id
}

\begin{abstract}
ABSTRAK
Latar Belakang : Upaya penanggulangan gizi kurang sebenarnya sudah dilakukan melalui pembinaan kader-kader posyandu, dan juga melalui penyuluhan gizi. Pentingnya pengetahuan kader tentang gizi kurang adalah agar kader mampu memberikan penyuluhan secara langsung pada ibu balita yang balitanya mengalami gizi kurang.

Tujuan : Penelitian ini bertujuan untuk mengetahui gambaran pengetahuan kader tentang gizi kurang pada balita di Kelurahan Rejoso Klaten.

Metode : Jenis penelitian ini adalah deskriptif dengan pendekatan cross sectional. Populasi dalam penelitian ini adalah semua kader di Kelurahan Rejoso Klaten dengan jumlah 30 kader. Alat pengumpulan data menggunakan kuesioner. Analisis data menggunakan jenis distribusi frekuensi

Hasil : Penelitian menunjukkan bahwa tingkat pengetahuan kader mayoritas berpengetahuan cukup sejumlah 24 kader (80\%). Berdasarkan karakteristiknya sebagian besar kader berumur 36-45 tahun sejumlah 11 responden (36,7\%), berpendidikan SD sejumlah 13 responden (43,3\%), lama menjadi kader 6-10 tahun sejumlah 18 responden $(60 \%)$, dan pekerjaan nya tidak bekerja sebanyak 21 responden $(70 \%)$.

Simpulan : Dalam penelitian ini pengetahuan kader tentang gizi kurang pada balita di Kelurahan Rejoso Klaten termasuk dalam kategori cukup.
\end{abstract}

Kata Kunci : pengetahuan, kader, gizi kurang pada balita.

\section{ABSTRACT}

Background: Nutrition prevention efforts are carried out by fostering posyandu cadres, and also through nutrition counseling. The importance of cadres' knowledge about malnutrition is so that cadres are able to provide counseling directly to mothers of children under five who have malnutrition.

The Purpose : the purpose of this study was to find out the description of cadre knowledge about malnutrition in children under five in Rejoso Klaten.

Method: This type of research is descriptive with a cross sectional approach. The population in this study were all cadres in the Rejoso Klaten District with 30 cadres.The data collection tool uses a questionnaire. Data analysis uses a type of frequency distribution. 
Result : The study shows that the knowledge level of the majority of cadres with knowledge is quite 24 cadres (80\%). Based on the characteristics of most cadres aged 36-45 years a number of 11 respondents (36.7\%), elementary school education numbered 13 respondents (43.3\%), a long time being a 6-10 year cadre of 18 respondents (60\%), and their jobs not working as many as 21 respondents (70\%).

Conclusion : In this study the cadre's knowledge of malnutrition in children under five in the Rejoso Klaten distric was included in the sufficient category.

Keywords: knowledge, cadres, malnutrition in children under five.

\section{PENDAHULUAN}

Makanan memberikan sejumlah zat gizi yang diperlukan untuk tumbuh kembang pada setiap tingkat perkembangan dan usia yaitu masa bayi, masa usia balita, masa usia pra sekolah (Syahmin, 2014). Pada bayi atau anak balita yang kekurangan gizi mengakibatkan terganggunya pertumbuhan dan perkembangan, disamping itu bayi sangat rentan terhadap penyakit-penyakit infeksi, termasuk diare dan infeksi saluran akut, utamanya penumonia. Oleh sebab itu, perbaikan gizi masyarakat yang difokuskan pada perbaikan bayi dan anak balita merupakan awal dalam meningkatkan derajat kesehatan masyarakat (Notoatmodjo,2006).

Menurut WHO lebih dari 50\% kematian bayi dan anak terkait dengan gizi kurang dan gizi buruk, oleh karena itu masalah gizi perlu ditangani secara cepat dan tepat. ${ }^{3}$ Rata-rata setiap provinsi pada tahun 2013 balita yang mengalami kurang gizi berjumlah 19,6 persen, hal ini naik dari 18,4 persen. Sedangkan daerah yang paling tinggi angka balita kekurangan gizi ialah NTT sekitar 34 persen. Jumlah balita yang mengalami gizi buruk sebanyak 5,7 persen dan yang mengalami gizi kurang sebanyak 13,9 persen. Sedangkan kecenderungan nasional 2013 proporsi anak yang kurus 6,8 persen sedangkan yang sangat kurus 5,3 persen (Budihardja,2011).

Pada tahun 2014 di Kabupaten Klaten, jumlah penderita gizi buruk sebanyak 23 orang, dibandingkan dengan tahun 2013 pada tahun 2014 ini penderita gizi buruk mengalami peningkatan sebanyak 12 orang. Berdasarkan pantauan status gizi (PSG) 2017 yang dilakukan Kementerian Kesehatan, bayi usia dibawah lima tahun (balita) yang mengalami masalah gizi pada 2017 mencapai 17,8\%, sama dengan tahun sebelumnya. Jumlah tersebut terdiri dari balita yang mengalami gizi buruk 3,8\% dan 14\% gizi kurang (Kemenkes, 2016).

Masalah gizi pada umumnya disebabkan oleh dua hal yaitu faktor primer dan sekunder. Faktor primer adalah bila susunan makanan seseorang salah dalam kuantitas atau kualitas yang disebabkan oleh kurangnya penyediaan pangan, kurang baiknya distribusi pangan, konsumsi pangan, kemiskinan, ketidaktahuan yang memungkinkan kebiasaan makan yang salah, sedangkan faktor sekunder meliputi semua faktor yang menyebabkan zat-zat gizi tidak sampai di sel-sel tubuh setelah makanan dikonsumsi, misalnya faktor-faktor menyebabkan terganggunya pencernaan, kelainan struktur cerna (Sunita,2006) 
Permasalahan gizi secara umum tersebut menimbulkan berbagai macam penyakit yaitu penyakit kurang energi protein (KEP) yang disebabkan oleh kekurangan energi dan protein. Penyakit anemia gizi yang disebabkan oleh kekurangan protein, vitamin $\mathrm{C}$, asam folat, vitamin $\mathrm{B}_{12}$, dan zat besi (fe), penyakit angular stomatitis yang merupakan penyakit disebabkan kekurangan riboflavin, penyakit keratomalasia akibat kekurangan vitamin A, penyakit rakhitis akibat kekurangan vitamin $\mathrm{D}$, penyakit skorbut/sariawan disebabkan kurang vitamin $\mathrm{C}$, penyakit gondok disebabkan kekurangan yodium, penyakit hati karena toksin yang ada dalam makanan seperti aflatoksin pada kacang-kacangan, penyakit beriberi karena kekurangan vitamin $B$ dan penyakit jantung/hipertensi akibat kelebihan lemak atau kolesterol (Budihardja,2011). Penyakit akibat kekurangan gizi pada balita tersebut biasanya disebut marasmus dengan gejala perut buncit, otot mengecil, wajah pucat, rambut mudah rontok, cengeng dan kurang nafsu makan. Akibat dari kekurangan gizi tersebut maka pada saat usia 2 tahun pertama, anak menjadi tidak cerdas seperti teman sebayanya. Biasanya anak-anak yang kurang gizi juga bisa mengidap rabun senja, anemi gizi sehingga anak mudah jatuh sakit akibat daya tahan tubuhnya lemah (Rofiq,2008).

Faktor-faktor yang dapat mendorong dan mempermudah terjadinya gizi kurang pada anak dapat bersumber dari masyarakat, yaitu kemiskinan, bahan makanan yang tidak tersedia atau sulit diperoleh, ketidaktahuan, sanitasi lingkungan, pelayanan kesehatan yang kurang memadai (Ekky,MR,2003).

Upaya penanggulangan gizi kurang sebenarnya sudah dilakukan melalui pembinaan kader-kader posyandu, dan juga melalui penyuluhan gizi. Hal ini telah dilakukan melalui posyandu oleh kader-kader yang telah dibina, agar bisa mensosialisasikan pengetahuan tentang gizi. Seperti halnya salah satu manfaat posyandu yaitu mendukung perbaikan perilaku, keadaan gizi dan kesehatan keluarga. Dilihat dari peran diatas memang sebagai kader posyandu mempunyai tugas khusus untuk memberitahukan hari dan jam buka posyandu, menyiapkan peralatan untuk penyelenggaraan posyandu sebelum posyandu di mulai, bekerja pada sistem lima meja posyandu,dan melakukan penyuluhan (Ismawati,2010).

Studi pendahuluan yang telah dilakukan oleh peneliti yaitu berdasarkan data dari Bidan Desa Kelurahan Rejoso Tahun 2018 dimana terdapat 578 balita. Berdasarkan dari hasil penimbangan berat badan bulan Juli balita yang mengalami gizi kurang sebanyak 52 balita dan yang mengalami gizi buruk sebanyak 6 balita. Dan jumlah kader di Kelurahan Rejoso sebanyak 35 orang. Berdasarkan data tersebut, peneliti tertarik untuk melakukan penelitian tentang "Gambaran Pengetahuan Kader Tentang Gizi Kurang Pada Balita Di Kelurahan Rejoso Klaten".

\section{METODE PENELITIAN}

Jenis penelitian ini adalah deskriptif dengan pendekatan cross sectional. Alat pengumpulan data menggunakan kuesioner. Populasi dalam penelitian ini adalah seluruh kader yang ada di kelurahan Rejoso yang berjumlah 35 orang. Teknik pengambilan sampel menggunakan teknik accidental sampling sehingga diperoleh 30 orang kader. Instrumen dalam penelitian ini menggunakan kuesioner yang Gambaran Pengetahuan Kader Tentang Gizi Kurang Pada Balita Di Kelurahan Rejoso Klaten (Ajeng Novita Sari, Danik Riawati) 
terlebih dahulu dilakukan uji validitas dengan menggunakan rumus person product momment. Berdasarkan hasil uji validitas dari 36 soal terdapat 4 butir soal dengan hasil $r_{\text {hitung }}<r_{\text {tabel }}$ yang artinya tidak valid dan selanjutnya soal yang tidak valid dihilangkan atau tidak dipakai dalam penelitian. Teknik yang digunakan untuk uji reliabilitas kuesioner pengetahuan menggunakan menggunakan K-R 20, dengan hasil perhitungan reliabilitas sangat tinggi menunjukan bahwa kuesioner pengetahuan memiliki koefisien reliabilitas sebesar 0,973. Metode pengumpulan data menggunakan data primer dan data sekunder. Pengambilan data primer dilakukan dengan membagikan kuesioner kepada responden, sebelum mengisi kuesioner responden diberi penjelasan tentang cara mengisi kuesioner dan selanjutnya memberikan informed consent yang diikuti penyerahan kuesioner. Setelah kuesioner diterima oleh responden, responden langsung mengisi kuesioner yang diberikan sesuai dengan ketentuan yang ada. Selanjutnya kuesioner dikumpulkan oleh peneliti untuk diperiksa kelengkapan jawaban, bila kurang lengkap dikembalikan pada responden untuk dilengkapi. Data sekunder berupa daftar nama kader, ibu bayi dan balita pada bulan Juli tahun 2018. Teknik pengolahan data dalam penelitian ini adalah editing, codding sheet, data entry, dan tabulating. Analisa data dalam penelitian ini menggunakan distribusi frekuensi.

\section{HASIL DAN PEMBAHASAN}

Tabel 1 Distribusi Frekuensi Pengetahuan Kader Tentang Gizi Kurang pada Balita di Kelurahan Rejoso Klaten.

\begin{tabular}{ccc}
\hline Kategori & Frekuensi & Prosentase (\%) \\
\hline Baik & 3 & 10 \\
Cukup & 24 & 80 \\
Kurang & 3 & 10 \\
Jumlah & 30 & 100 \\
\hline
\end{tabular}

Dari tabel 1 diatas menunjukan bahwa dari 30 responden tingkat pengetahuan tentang gizi kurang pada balita sebagian besar masuk dalam kategori cukup yaitu sebanyak 24 responden $(80 \%)$.

Tabel 2 Distribusi Frekuensi Karakteristik Responden Berdasarkan Umur di Kelurahan Rejoso Klaten

\begin{tabular}{ccc}
\hline Umur (Tahun) & Frekuensi & Prosentase (\%) \\
\hline $15-25$ tahun & 0 & 0 \\
$26-35$ tahun & 5 & 16,7 \\
$36-45$ tahun & 14 & 46,7 \\
$46-55$ tahun & 11 & 36,7 \\
Jumlah & 30 & 100 \\
\hline
\end{tabular}

Dari tabel 2 diatas menunjukkan bahwa dari 30 responden sebagaian besar umur responden berumur 36-45 tahun yaitu sebanyak 14 responden (46,7\%). 
Tabel 3 Distribusi Frekuensi Karakteristik Responden Berdasarkan Pendidikan di Kelurahan Rejoso Klaten

\begin{tabular}{ccc}
\hline Pendidikan & Frekuensi & Prosentase (\%) \\
\hline SD & 15 & 50 \\
SMP & 5 & 16,7 \\
SMA & 5 & 16,7 \\
PT & 5 & 16,7 \\
Jumlah & 30 & 100 \\
\hline
\end{tabular}

Dari tabel 3 diatas menunjukkan bahwa dari 30 responden responden sebagian besar berpendidikan SD yaitu sebanyak 15 responden (50\%).

Tabel 4 Distribusi Frekuensi Karakteristik Responden Berdasarkan Lama Menjadi Kader di Kelurahan Rejoso Klaten

\begin{tabular}{ccc}
\hline Lama Kerja & Frekuensi & Prosentase (\%) \\
\hline 1-5 tahun & 9 & 30 \\
6-10 tahun & 21 & 70 \\
Jumlah & 30 & 100 \\
\hline
\end{tabular}

Dari tabel 4 diatas menunjukkan bahwa dari 30 responden sebagaian besar umur responden berumur 6-10 tahun yaitu sebanyak 21 responden (70\%).

Tabel 5 Distribusi Frekuensi Karakteristik Responden Berdasarkan Pekerjaan di Kelurahan Rejoso Klaten.

\begin{tabular}{ccc}
\hline Pekerjaan & Frekuensi & Prosentase (\%) \\
\hline Bekerja & 6 & 20 \\
Tidak bekerja & 24 & 80 \\
Jumlah & 30 & 100 \\
\hline
\end{tabular}

Dari tabel 5 diatas bahwa dari 30 responden sebagian besar tidak berkerja yaitu sebanyak 24 responden $(80 \%)$.

Tabel 6 Distribusi Frekuensi Pengetahuan Kader Tentang Gizi Kurang Pada Balita di Kelurahan Rejoso Klaten Berdasarkan Karakteristik Umur, Pendidikan, Lama Menjadi Kader dan Pekerjaan

\begin{tabular}{|c|c|c|c|c|c|c|c|c|}
\hline \multirow{3}{*}{ karakteristik } & \multicolumn{6}{|c|}{ Tingkat Pengetahuan } & \multirow{2}{*}{\multicolumn{2}{|c|}{ Responden }} \\
\hline & \multicolumn{2}{|c|}{ Baik } & \multicolumn{2}{|c|}{ Cukup } & \multicolumn{2}{|c|}{ Kurang } & & \\
\hline & $\mathrm{F}$ & $\%$ & $\mathrm{~F}$ & $\%$ & $\mathrm{~F}$ & $\%$ & $\sum$ & $\%$ \\
\hline \multicolumn{9}{|l|}{ Umur } \\
\hline $15-25$ & 0 & 0 & 0 & 0 & 0 & 0 & 0 & 0 \\
\hline $26-35$ & 1 & 3,3 & 4 & 13,3 & 0 & 0 & 5 & 16,7 \\
\hline $36-45$ & 1 & 3,3 & 11 & 36,7 & 2 & 6,7 & 14 & 46,7 \\
\hline $46-55$ & 1 & 3,3 & 9 & 30,0 & 1 & 3,3 & 11 & 36,6 \\
\hline Jumlah & 3 & 10 & 24 & 80,0 & 3 & 10 & 30 & 100 \\
\hline \multicolumn{9}{|l|}{ Pendidikan } \\
\hline SD & 0 & 0 & 13 & 43,3 & 2 & 6,7 & 15 & 50 \\
\hline SMP & 1 & 3,3 & 4 & 13,3 & 1 & 3,3 & 6 & 20 \\
\hline SMA & 1 & 3,3 & 3 & 10 & 0 & 0 & 4 & 13,3 \\
\hline PT & 1 & 3,3 & 4 & 13,3 & 0 & 0 & 5 & 16,7 \\
\hline Jumlah & 3 & 10 & 24 & 80 & 3 & 10 & 30 & 100 \\
\hline
\end{tabular}




$\begin{array}{lcccccccc}\begin{array}{l}\text { Lama kerja } \\ \text { 1-5 tahun }\end{array} & 0 & 0 & 6 & 20 & 3 & 10 & 9 & 20 \\ \text { 6-10 tahun } & 3 & 10 & 18 & 60 & 0 & 0 & 21 & 80 \\ \text { Jumlah } & 3 & 10 & 24 & 80 & 3 & 10 & 30 & 100 \\ & & & & & & & & \\ \text { Pekerjaan } & & & & & & & & \\ \text { Bekerja } & 2 & 6,7 & 3 & 10 & 1 & 3,3 & 6 & 20 \\ \quad \text { Tidak } & 1 & 3,3 & 21 & 70 & 2 & 6,7 & 24 & 80 \\ \text { Bekerja } & 3 & 10 & 24 & 80 & 3 & 10 & 30 & 100 \\ \text { Jumlah } & & & & & & & & \end{array}$

Berdasarkan tabel 6 menunjukkan bahwa sebagian besar pengetahuan kader tentang gizi kurang pada balita berdasarkan karakteristik umur sebagian besar dengan kategori cukup pada umur 36-45 tahun sebanyak 11 responden $(36,7 \%)$ dan paling sedikit berumur 26-35 tahun sebanyak 4 responden (13,3\%).

Pengetahuan kader tentang gizi kurang pada balita berdasarkan pendidikan sebagian besar dengan kategori cukup dengan pendidikan foramal SD sebanyak 13 responden $(43,3 \%)$ dan sebagian kecil berpendidikan SMA sebanyak (10\%).

Pengetahuan kader tentang gizi kurang pada balita berdasarkan lama menjadi kader sebagian besar dengan kategori cukup dengan lama kerja 6-10 tahun sebanyak 18 responden (60\%) dan sebagian kecil dengan lama kerja 1-5 tahun sebanyak 6 responden $(20 \%)$.

Pengetahuan kader tentang gizi kurang pada balita berdasarkan pekerjaan sebagian besar dengan kategori cukup dengan tidak bekerja sebanyak 21 responden $(70 \%)$ dan sebagian kecil dengan bekerja sebanyak 3 responden $(10 \%)$.

Berdasarkan tabel 1 dapat diketahui bahwa tingkat pengetahuan responden tentang gizi kurang pada balita dalam kategori cukup sebanyak 24 responden (80\%). Dilihat dari umur mayoritas responden berumur 36-45 tahun sebanyak 11 responden $(36,7 \%)$, jadi semakin banyak umur responden semakin banyak pula pengetahuannya. Berdasarkan dari teori semakin cukup umur maka semakin tinggi tingkat kematangan dan kekuatan seseorang sehingga cara berfikir dan bekerja seseorang semakin optimal. Kepercayaan masyarakat terhadap seseorang yang lebih dewasa akan meningkat (Arikunto,2006).

Dilihat dari lama kerja mayoritas responden sudah menjadi kader 6-10 tahun sebanyak 18 responden (60\%), jadi semakin lama responden menjadi kader maka semakin banyak pula pengetahuan yang di dapat. Masa kerja seorang kader akan memberikan pengalaman dan pengetahuan yang lebih baik dibandingkan dengan teori yang diperoleh selama menjalani masa pendidikan. Berdasarkan teori masa kerja sebagai kader kesehatan yang lebih lama akan memberikan masukan dan pengalaman yang lebih baik terhadap kader tersebut.(Yulifah,2009)

Dilihat dari pekerjaan mayoritas responden tidak bekerja sebanyak 21 responden $(70 \%)$, jadi responden tersebut mempunyai banyak waktu dan aktif untuk mengikuti kegiatan seperti posyandu, penyuluhan - penyuluhan tentang gizi dan pelatihan yang diadakan oleh tenaga kesehatan. Pekerjaan bukanlah sumber kesenangan, tetapi lebih banyak merupakan cara mencari nafkah yang membosankan, berulang dan banyak tantangan. Sedangkan pekerjaan umumnya merupakan kegiatan yang menyita waktu, sehingga juga dapat berpengaruh pada pengetahuan.(Arikunto,2006)

Gambaran Pengetahuan Kader Tentang Gizi Kurang Pada Balita Di Kelurahan Rejoso Klaten (Ajeng Novita Sari, Danik Riawati) 
Pada pengetahuan dengan kategori baik ada 3 responden (10\%), dilihat dari lama kerja responden sudah 6-10 tahun, jadi semakin lama responden menjadi kader maka semakin banyak pula pengetahuan yang di dapat. Masa kerja seorang kader akan memberikan pengalaman dan pengetahuan yang lebih baik dibandingkan dengan teori yang diperoleh selama menjalani masa pendidikan. Berdasarkan teori masa kerja sebagai kader kesehatan yang lebih lama akan memberikan masukan dan pengalaman yang lebih baik terhadap kader tersebut.(Yulifah,2009)

Dilihat dari pendidikan responden memiliki pendidikan yang menengah yaitu SMP, SMA dan PT masing-masing 1 responden $(3,33 \%)$, sehingga dalam kemampuan menyerap informasi yang diperoleh cukup baik. Hal ini sesuai dengan teori, pengetahuan sangat erat kaitannya dengan pendidikan dimana diharapkan seseorang dengan pendidikan tinggi, maka orang tersebut semakin luas pula pengetahuannya, namun perlu di tekankan bahwa seorang dengan pendidikan rendah tidak berarti mutlak berpengetahuan rendah pula. Pengetahuan tidak mutlak diperoleh melalui pendidikan formal meliputi tingkat dasar (SD), menengah (SMP, SMA), dan tingkat perguruan tinggi (Akademi, PT).(Arikunto,2006)

Pada pengetahuan dengan kategori kurang ada 3 responden (10\%), dari pendidikan SD sebanyak 2 responden $(6,7 \%)$, jadi kurangnya pengetahuan di sebabkan karena responden berpendidikan dasar. Berdasarkan teori, pengetahuan sangat erat kaitannya dengan pendidikan dimana diharapkan seseorang dengan pendidikan tinggi, maka orang tersebut semakin luas pula pengetahuannya, namun perlu di tekankan bahwa seorang dengan pendidikan rendah tidak berarti mutlak berpengetahuan rendah pula. Pengetahuan tidak mutlak diperoleh melalui pendidikan formal meliputi tingkat dasar (SD), menengah (SMP, SMA), dan tingkat perguruan tinggi (Akademi, PT). (Arikunto,2006) Berdasarkan lama kerja 1-5 tahun sebanyak 3 responden (10\%), jadi lama menjadi kader juga sangat berpengaruh terhadap pengetahuan karena responden belum banyak mendapatkan pengetahuan tentang gizi pada balita. Masa kerja seorang kader akan memberikan pengalaman dan pengetahuan yang lebih baik dibandingkan dengan teori yang diperoleh selama menjalani masa pendidikan. Berdasarkan teori masa kerja sebagai kader kesehatan yang lebih lama akan memberikan masukan dan pengalaman yang lebih baik terhadap kader tersebut.(Yulifah,2009)

Faktor-faktor yang mempengaruhi pengetahuan yaitu umur, pendidikan, pekerjaan, lama menjadi kader dan pekerjaan. Seperti yang terdapat pada teori, pengetahuan dipengaruhi oleh pendidikan, usia, informasi, pengalaman, media cetak, media elektronik dan lain-lain. (Arikunto,2006)

Pada tabel 2 menujukkan bahwa sebagian besar responden berumur 36-45 tahun yaitu sebanyak 14 responden (46,7\%). Meskipun usia tersebut bukan termasuk usia yang produktif, tetapi mereka mempunyai pengalaman yang banyak karena responden tersebut menjadi kader lebih lama, sehingga pengetahuan responden cukup.

Semakin cukup umur maka semakin tinggi tingkat kematangan dan kekuatan seseorang sehingga cara berfikir dan bekerja seseorang semakin optimal. 
Kepercayaan masyarakat terhadap seseorang yang lebih dewasa akan meningka. (Arikunto,2006)

Pada tabel 3 menunjukkan bahwa sebagian besar responden berpendidikan SD yaitu sebanyak 15 orang (50\%). Meskipun responden tersebut berpendidikan dasar tetapi pendidikan belum tentu mempengaruhi pengetahuan seseorang.

Pengetahuan sangat erat kaitannya dengan pendidikan dimana diharapkan seseorang dengan pendidikan tinggi, maka orang tersebut semakin luas pula. Pengetahuan tidak mutlak diperoleh melalui pendidikan formal meliputi tingkat dasar (SD), menengah (SMP, SMA), dan tingkat perguruan tinggi (Akademi, PT). (Arikunto,2006)

Pada Tabel 4 menunjukkan bahwa sebagian besar responden Lama menjadi kader 6-10 tahun yaitu sebanyak 21 orang (70\%), dan paling sedikit lama menjadi kader 1-5 tahun yaitu sebanyak 9 orang (30\%). Semakin lama responden menjadi kader maka semakin banyak pula pengetahuannya. Masa kerja sebagai kader kesehatan yang lebih lama akan memberikan masukan dan pengalaman yang lebih baik terhadap kader tersebut.(Yulifah,2009)

Pada Tabel 5 menunjukkan bahwa sebagian besar responden tidak bekerja yaitu sebanyak 24 responden (80\%), dan paling sedikit bekerja yaitu sebanyak 6 responden $(20 \%)$. Selain faktor umur, pendidikan dan lama menjadi kader pekerjaan juga berpengaruh terhadap pengetahuan, karena kader yang tidak bekerja memiliki waktu yang tidak terbatas dibandingkan dengan kader yang bekerja sehingga dapat selalu ikutserta dalam kegiatan posyandu.

Pekerjaan bukanlah sumber kesenangan, tetapi lebih banyak merupakan cara mencari nafkah yang membosankan, berulang dan banyak tantangan. Sedangkan pekerjaan umumnya merupakan kegiatan yang menyita waktu, sehingga juga dapat berpengaruh pada pengetahuan.(Arikunto,2006)

Berdasarkan tabel 6 tentang pengetahuan kader tentang gizi kurang pada balita dengan kategori baik terdapat 3 responden $(10 \%)$ berpengetahuan baik, dengan pendidikan SMP, SMA dan PT, lama menjadi kader 6-10 tahun dan kebanyakan kader yang bekerja. Faktor yang mempengaruhi pengetahuan responden tersebut adalah memiliki pendidikan yang menengah sehingga dalam kemampuan menyerap informasi yang diperoleh cukup baik dan dipengaruhi oleh lama kerja, dimana responden mempunyai pengalaman yang banyak sehingga pengetahuan responden tersebut baik.

Hal ini sesuai dengan teori, pengetahuan sangat erat kaitannya dengan pendidikan dimana diharapkan seseorang dengan pendidikan tinggi, maka orang tersebut semakin luas pula pengetahuannya, namun perlu di tekankan bahwa seorang dengan pendidikan rendah tidak berarti mutlak berpengetahuan rendah pula. Pengetahuan tidak mutlak diperoleh melalui pendidikan formal meliputi tingkat dasar (SD), menengah (SMP, SMA), dan tingkat perguruan tinggi (Akademi, PT) (Arikunto,2006).

Masa kerja seorang kader akan memberikan pengalaman dan pengetahuan yang lebih baik dibandingkan dengan teori yang diperoleh selama menjalani masa pendidikan. Masa kerja sebagai kader kesehatan yang lebih lama akan memberikan masukan dan pengalaman yang lebih baik terhadap kader tersebut (Yulifah,2009).

Gambaran Pengetahuan Kader Tentang Gizi Kurang Pada Balita Di Kelurahan Rejoso Klaten (Ajeng Novita Sari, Danik Riawati) 
Pengetahuan responden tentang gizi kurang pada balita dengan kategori kurang terdapat 3 responden (10\%), berdasarkan karakteristik responden tersebut sebagian besar berumur 36-45 tahun, berpendidikan SD, lama menjadi kader 1-5 tahun dan sebagian besar tidak bekerja. Faktor yang mempengaruhi pengetahuan responden tersebut adalah umur yang sudah tidak produktif lagi sehingga daya ingat yang dimiliki sudah sedikit menurun, sedangkan pada pendidikan responden tersebut berpendidikan dasar sehingga pengetahuannya kurang luas dan lama menjadi kader juga sangat berpengaruh terhadap pengetahuan karena responden belum banyak mendapatkan pengetahuan tentang gizi pada balita.

Hal ini sesuai dengan teori, pengetahuan sangat erat kaitannya dengan pendidikan dimana diharapkan seseorang dengan pendidikan tinggi, maka orang tersebut semakin luas pula pengetahuannya (Arikunto,2006).

Masa kerja seorang kader akan memberikan pengalaman dan pengetahuan yang lebih baik dibandingkan dengan teori yang diperoleh selama menjalani masa pendidikan. Masa kerja sebagai kader kesehatan yang lebih lama akan memberikan masukan dan pengalaman yang lebih baik terhadap kader tersebut. ${ }^{17}$

Pengetahuan responden tentang gizi kurang pada balita dengan kategori cukup sebanyak 24 responden (80\%), berdasarkan karakteristik responden tersebut sebagian besar berumur 36-45 tahun, berpendidikan SD, lama menjadi kader 6-10 tahun, dan tidak bekerja. Faktor yang mempengaruhi pengetahuan responden tersebuat adalah umur karena semakin banyak umur responden semakin banyak pula pengetahuannya, kemudian lama menjadi kader juga sangat berpengaruh pada pengetahuan dikarenakan dengan lama kerja 6-10 tahun responden mempunyai pengalaman yang banyak sehingga pengetahuan responden tersebut cukup, dan juga responden yang berpengetahuan cukup sebagian besar tidak bekerja dikarenakan responden tersebut mempunyai banyak waktu dan aktif untuk mengikuti kegiatan seperti posyandu, penyuluhan - penyuluhan tentang gizi dan pelatihan yang diadakan oleh tenaga kesehatan.

Berdasarkan dari teori semakin cukup umur maka semakin tinggi tingkat kematangan dan kekuatan seseorang sehingga cara berfikir dan bekerja seseorang semakin optimal. Kepercayaan masyarakat terhadap seseorang yang lebih dewasa akan meningkat (Arikunto,2006).

Masa kerja seorang kader akan memberikan pengalaman dan pengetahuan yang lebih baik dibandingkan dengan teori yang diperoleh selama menjalani masa pendidikan. Masa kerja sebagai kader kesehatan yang lebih lama akan memberikan masukan dan pengalaman yang lebih baik terhadap kader tersebut (Yulifah,2009).

Pekerjaan bukanlah sumber kesenangan, tetapi lebih banyak merupakan cara mencari nafkah yang membosankan, berulang dan banyak tantangan. Sedangkan pekerjaan umumnya merupakan kegiatan yang menyita waktu, sehingga juga dapat berpengaruh pada pengetahuan (Arikunto,2006).

Penelitian ini sama dengan penelitian yang dilakukan oleh Nanik Tri Wahyuni pada tahun 2011 dimana dari hasil penelitian yang dilakukan sebagian besar ibu memiliki pengetahuan cukup tentang gizi kurang (Wahyuni, 2011) 
Penelitian ini tidak sama dengan penelitian yang dilakukan oleh Ayu Agustin pada tahun 2011 dimana dari hasil penelitian yang dilakukan sebagian besar kader memiliki pengetahuan kurang tentang perkembangan pada balita (Agustin,2011).

\section{SIMPULAN DAN SARAN}

\section{Simpulan}

Gambaran Pengetahuan Kader Tentang Gizi Kurang Pada Balita di Kelurahan Rejoso Klaten didapatkan hasil bahwa tingkat pengetahuan kader berpengetahuan cukup yaitu sebanyak 24 responden $(80 \%)$. Karakteristik kader berdasarkan umur paling banyak berumur 46-50 tahun sebanyak 14 responden (46.7\%), berdasarkan pendidikan paling banyak SD sebanyak 15 responden $(50 \%)$, berdasarkan lama menjadi kader paling banyak 6-10 tahun sebanyak 21 responden (70\%), dan berdasarkan pekerjaan paling banyak tidak bekerja sebanyak 24 responden (80\%). Gambaran Pengetahuan Kader Tentang Gizi Kurang Pada Balita di Kelurahan Rejoso Klaten berdasarkan karakteristik umur sebagian besar dalam kategori cukup yaitu 36-45 tahun. Pengetahuan responden berdasarkan karakteristik pendidikan sebagian besar dalam kategori cukup berasal dari pendidikan SD. Pengetahuan responden berdasarkan karakteristik lama menjadi kader sebagian besar dalam kategori cukup yaitu 6-10 tahun. Pengetahuan responden berdasarkan karakteristik pekerjaan sebagian besar dalam kategori cukup yaitu tidak bekerja.

\section{Saran}

Diharapkan para kader untuk lebih meningkatkan pengetahuan khususnya tentang gizi kurang pada balita dengan cara mengikuti penyuluhan tentang gizi kurang pada balita. Bagi tenaga kesehatan diharapkan dapat meningkatkan penyuluhan kepada masyarakat, khususnya penyuluhan tentang gizi pada balita. Bagi peneliti selanjutnya diharapkan melakukan penelitian mengenai status gizi dengan variabel yang lain.

\section{DAFTAR PUSTAKA}

Arikunto, S. 2002. Prosedur Penelitian Suatu Pendekatan Praktek Edisi Revisi. Jakarta : Rineka Cipta.

Arikunto. 2006. Prosedur Penelitian. Jakarta : Rineka Cipta. Halaman 131

Atikah, P. 2010. Ilmu Gizi. Yogyakarta : Nuha Medika.

Ayu Agustin, 2011. Judul Gambaran Pengetahuan Kader Di Posyandu Desa Cipacing Tentang Perkembangan Pada Balita.

Budihardja, DR.DTM\&G, MPH, 2011. Kader posyandu menuju keluarga sadar gizi. Kementrian Kesehatan Republik Indonesia Tahun 2011.

Budihardja, DR.DTM\&G, MPH, 2011.Pedoman Pelayanan Anak Gizi Buruk. Direktur Jendral Bina Gizi dan Kesehatan Ibu dan Anak, Februari 2011. Kementrian Kesehatan Republik Indonesia, Jakarta.

Depkes. 2007. MDGS 2015, http:// www.depkes.go.id diakses pada tanggal 15 Februari 2019 pukul 11.30. 
Ekky MR, 2003, Kebutuhan Gizi Ibu Hamil. Ebers papyrus. Vol.2 No.2, Jakarta http://www.dinkesjatengprov.go.id/dokumen/2013/SDK/Mibangkes

Ismawati, C.2010. Posyandu dan Desa Siaga. Yogyakarta: Nuha Medika

Nanik Tri Wahyuni, 2011. Judul Tingkat Pengetahuan Ibu Tentang Gizi Kurang Pada Balita penelitian ini dilakukan pada Tahun 2011 Di Posyandu Lestari II Mancasan Baki Sukoharjo.

Notoatmodjo. 2003. Metodologi Penelitian Kesehatan. Jakarta : Rineka Cipta.

Notoatmodjo. 2005. Metodologi Penelitian Kesehatan. Jakarta : Rineka Cipta.

Riyas Widiyati, 2010. Judul Faktor-faktor yang Berhubungan dengan Gizi Kurang pada Balita penelitian ini dilakukan pada bulan Mei sampai Juni Tahun 2009 di Desa Tanduk, Kecamatan Ampel, Kabupaten Boyolali.

Rofiq, Ahmad, 2008. Gizi Buruk. By: ahmad rofiq di sampaikan pada 12 Mei 2013.http://ahmadrofiq.com/?p=50); 19.06

Soekidjo notoatmodjo, 2007. Ilmu kesehatan Masyarakat., PT.Rineka Cipta. Jakarta.

Sunita Almatsier, 2006. Prinsip Dasar Ilmu Gizi. PT.Gramedika Pustaka Utama, Jakarta

Sunita. 2002. Prinsip Dasar Ilmu Gizi. Jakarta : Gramedia Pustaka Utama.

Susiana eti,2012, Gambaran Status Gizi batita di posyandu melati gedongan baki sukoharjo.

Syahmin Moehyi.2004. Bayi Sehat dan Cerdas Melalui Gizi dan Makanan Pilihan Pedoman Asupan Gizi untuk Bayi dan Balita. Pustaka Mina, Jakarta.

Trihono, data Riskesdas, Penyebab ibu dan anak Indonesia kurang gizi 2013, http://www.tempo.co/read/news/2012/01/18/173378104/RI-Negara-diUrutan-ke-5-yang-Warganya-Kurang-Gizi

Widjaja, M. 2002. Gizi Tepat Untuk Perkembangan Otak dan Kesehatan Balita. Jakarta : Kawan Pustaka

Yulifah, R. 2009. Asuhan Kebidanan Komunitas. Jakarta : Salemba Medika www.kesmas.kemkes.go.id/assets/upload/dir../buku-saku-hasil-PSG2016 842.Pdf 